represent the University of London in Parliament. I find, however, that your letter addressed to me is understood to show that I agree with all the opinions expressed by you in that letter, and in justice to myself I must make known to my fellow electors and others how wholly we disagree on the above point, and how much I regret the attitude you assume in the matters in question.

$$
\text { "Sir John Lubbock, Bart." Yours very "M. Fos'rer. }
$$

The second has been addressed to Sir John Lubbock by the President and a number of Fellows of the Royal Society :-

$$
\text { "July 6, I895. }
$$

"Dear Sir John Lubbock,--The interests of learning and of education are so closely bound up with the future development of the University of London that we hope you will not regard us as interfering between yourself and the Electing Body of the University if we venture to express our regret at some of the opinions you have put forward in your Election address.

"You state that you would do your best to secure that the scheme (for the reorganisation of the University), when arranged, should be submitted to Convocation for their approval, to be signified as at a Senatorial Election, and would oppose the Bill unless this were conceded.

"You must allow us to point out that this proposal would confer upon Convocation a right, which is without precedent, to supervise the acts of a Commission entrusted with the reorganisation of the University of which Convocation itself is a part.

"The scheme of the 'Gresham Commissioners' has been approved not only by all the institutions concerned, but by the great body of educated public opinion. It is, however, certain that very grave difficulties will arise if the ultimate fate of the scheme is to depend upon the voting papers of Convocation.

"We, therefore, believe that the proposal you support, if adopted, will result in the failure of another attempt to establish a Teaching University in London, and will indefinitely postpone the solution of a question which, after prolonged discussion, seemed to be on the eve of settlement.

$$
\text { "We are, yours faithfully, }
$$

"KELVIN (P.R.S.), JOHN Evans (Treas.R.S.), M. Foster (Sec.R.S.), Joseph Lister, RaYleigh, Douglas Galton, T. G. Bonney, T. E. Thorpe, Horace Lamb, J. H. Poynting, ArThuR W. RÜCKER, E. FRANKLAND, N. STORY MASKELYNE, Henry E. Roscoe, P. H. PYe-Smith, J. NORMAN LOCKYer, JOHN ERIC ERICHSEN, WILliaM Ramsay, G. Carey Foster."

In his address, Sir John Lubbock states that the opinions of the present Government on the University question have yet to be made known. In view of the fact that the Commission, whose report has been so generally approved, was appointed during Lord Salisbury's last term of office, this attitude ought not to be doubtful.

\section{THE ELECTRICAL MEASUREMENT OF STARLIGHT}

$\mathrm{T}$ HAT the light of a star is able to produce at the surface of the earth a measurable effect, other than the action on a photographic plate, is a fact which was published in these pages in January last year. The light of stars and planets produces two effects-the one photographic and the other electric. The first-which has, of course, been known for many years - is slow in its operation; the second-which was discovered only a year ago in Mr. Wilson's observatory at Daramona, Westmeathis almost instantaneous.

NO. I 34 I, VOL. 52 ]
In order to obtain the electrical effect, a photoelectric cell of extremely great sensitiveness to light is employed. Such a cell is constructed with selenium, aluminium, and the liquid onanthol. If we take a strip of clean aluminium-say half an inch long, one-tenth of an inch wide, and thick enough to be fairly stiff-lay it on an iron plate which is heated by a Bunsen flame, and place on the end of the strip a very small particle of selenium, this selenium will melt and form a small black globule of liquid. Let the flame be now withdrawn, and the globule of melted selenium spread over the end of the aluminium strip, by means of a hot glass rod, so that it forms a thin uniform layer of area about $I$ of an inch square on the end of the strip, and let this dark layer cool to a few degrees below its melting point (about $217^{\circ}$ C.). Now apply heat again to the under surface of the iron plate until the aluminium strip becomes nearly hot enough to re-melt the layer of selenium. In this process the colour of the layer will gradually change from black to a greyish brown. When it is just on the point of melting, withdraw the heat and blow over its surface ; this will instantly check the tendency to melt, and will leave the surface of the selenium in the state in which it is most sensitive to light. If this strip (or rather its selenium-covered end) is immersed in a glass tube containing acetone or cenanthol, and connected with one pole of a quadrant electrometer, whose other pole is connected with a platinum wire sealed into the glass tube, we have a photoelectric cell, in which the action of light falling on the selenium layer results in giving the selenium a positive electric charge and the liquid a negative one, the former charge being conveyed to one pole of the electrometer by the aluminium plate, and the latter to the other pole by the platinum wire sealed into the cell.

Roughly speaking, the difference of potential produced in such a cell as this by ordinary diffused daylight is something between one-third and one-half of a volt.

Such were the seleno-aluminium cells used in the measurement of starlight in January 1894 , the liquid in them being onanthol. This liquid was found to be better than acetone (which had been previously used), not only because of the greater ease with which it can be sealed up in glass tubes, but because it does not act chemically on selenium, which acetone seems to do sooner or later. But it is obvious that a cell formed in this way contains an element of inconstancy; for, the strip of aluminium will at the same time convey to the insulated pole of the electrometer the positive charge generated by light in the selenium and a portion of the negative charge imparted to the liquid, so that the effective E.M.F. is less than it should be ; and, again, there will be currents circulating perpetually between the selenium and the back of the aluminium strip, and such currents deteriorate the cell. Hence it happened that such cells always fell off in strength after about six hours. They sufficed, however, to show very easily measurable electromotive forces from the light of the planets, and even from the light of Sirius.

Shortly after January $\mathbf{1} 894$, a very notable improvement was made in the construction of the cells, this improvement resulting from the perception of the cause of deterioration above explained. Instead of a strip of aluminium as a base for the selenium layer, the end of an aluminium wire, about one millimetre in diameter, was used. This wire was enclosed in a glass tube $(A, B$, in the figure on p. 247), into which it fitted tightly, one end of the wire being flush with an end of the tube. On this end was deposited the layer of selenium, with the same process of heating as that already described. The other end of the aluminium wire inside the glass tube was connected with a fine platinum wire, $P$, which emerged from the second end of the tube, and which formed the selenium pole of the photoelectric cell.

In this way the liquid is kept out of contact with the 
aluminium wire, and the deteriorating local currents in the cell are avoided, if the glass tube exactly fits round the aluminium wire; but this desirable result has not yet been perfectly attained, the liquid finding its way into the tube after some considerable time. However, in this way have been constructed cells which have remained constant for about three weeks.

In the figure, $\mathrm{C} \mathrm{C}$ is a cork in which the glass tube, $\mathrm{B}$, ontaining the aluminium wire at the end $A$ and the attached platinum wire, fits, this cork fitting tightly into the side of the glass cell which contains the liquid. The tube $\mathrm{B}$ passes close up to a quartz window, $Q \mathrm{Q}$, cemented to the cell opposite the cork $\mathrm{CC}$. The light of the star is received on the window, $Q Q$, and is made to fall on the selenium layer at the end $A$ of the tube $B$. A platinum wire, $\mathrm{P}^{\prime}$, is sealed into the bottom of the glass cell, and conveys the charge taken by the liquid to one pole of the electrometer, while the platinum wire $P$ conveys the charge taken by the selenium to the other pole of the electrometer; $\mathrm{S}$ is a ground stopper at the top of the cell, where the liquid is poured in.

This cell is fitted into a holder which can be fixed to a telescope in place of the eyepiece; and this cell-holder allows of the adjustments which are necessary to bring the point $\mathrm{A}$ to the position of the image of a star.

This is the form of photoelectric cell with which, in conjunction with Prof. Fitzgerald and Mr. W. E. Wilson, I measured the electromotive forces of the lights of

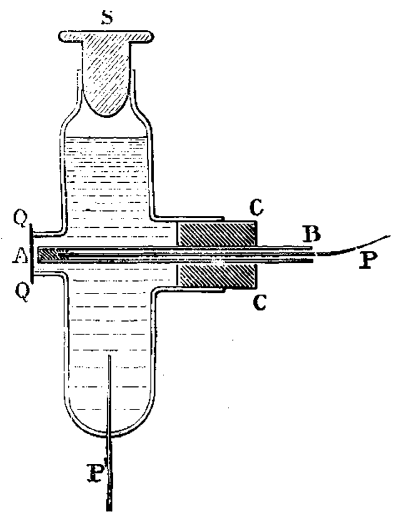

Tupiter, Saturn, Vega, Arcturus, Regulus, Irocyon, and some other stars last April, in Mr. Wilson's observatory at Daramona, Westmeath. The telescope used was Mr. Wilson's 2-feet reflector.

In order to give a notion of the sensitiveness of the cell to light, I may say that if an ordinary paraffin candle is held at a distance of 9 feet from the window $Q Q$, it will produce an electromotive force of "about ' 03 volts; or, to put the matter differently, suppose an ordinary quadrant electrometer, of Clifton's pattern, charged so that a Daniell cell gives a deflection of 400 divisions on the ordinary scale (placed at a metre distance); then the light of the candle at 9 feet falling on the photoelectric cell would give a deflection of twelve divisions, and the deflection varies inversely as the distance of the candle.

Now the light of Vega as concentrated in the 2-feet telescope gives a slightly greater deflection than the (of course unconcentrated) light of the candle; so that we are evidently dealing with easily measurable quantities.

The cell is sensitive to all the rays of the spectrum, but the maximum effect is produced by the yellow. It is sensitive to rays considerably below the visible red and beyond the blue.

The light of Arcturus was found to give 0.82 of the E.M.F. produced by the candle at 9 feet; the light of Saturn 0.56 , which was also about the value of the light of Regulus. Unfortunately neither Sirius nor Capella, NO. I 34 I, VOL. 52$]$ nor any star in Orion, nor any in the Great Bear, was available for our observations; but these we hope to include, before long, in the list of measured stars.

It will be observed that in this electrical measurement of starlight we do not measure currents, but electromotive forces-we do not use a galvanometer, but an electrometer; and an electrometer of small capacity was specially constructed for these experiments, with the aid of the Government grant dispensed by the Royal Society.

lt is not desirable to allow the light to generate currents: the electrical charges must be allowed to flow back into the cell, so that it may not be temporarily deteriorated during the observations. Hence the preference for the electrometer.

The space at my disposal will not allow of my entering into many details ; but I may mention, in particular, the importance of having the whole of the sensitive surface in the cell covered by the light of the star. It matters not to the value of the E.M.F. produced how far behind the focal image of the star the sensitive surface, $A$, is placed-provided that the image of the star just covers the surface A. This is essential in all photoelectric cells, and also in thermopiles; and the neglect of this condition may partly explain the failure of attempts to obtain thermoelectric indications from the stars and planets, although we should scarcely expect success from methods which aim at measuring merely a very limited portion of the radiation (viz. the heat, or infra-red). The photoelectric cell integrates the whole energy of the radiation on the sensitive surface; and the square of the observed E.M.F. is the measure of this incident energy,

It is interesting to know how the photelectric measures, so far as they have gone, compare with the photometric measures of "magnitudes" hitherto employed by astronomers. In the latter, if $\mathrm{B}$ and $\mathrm{B}$ ' are the "brightnesses" of two stars of the magnitudes $m$ and $m^{\prime}$ respectively, we have by definition

$$
\log _{10} \frac{\mathrm{B}}{\mathrm{B}^{\prime}}=\frac{4}{10}\left(m^{\prime}-m\right): \ldots . . . \text { ( }
$$

This equation defines merely the difference of the magnitudes, and the definition is quite arbitrary. The essential things are $B$ and $B^{\prime}$. How are they measured? The photoelectric method says that they are $\mathrm{E}^{2}$ and $\mathrm{E}^{\prime 2}$, the squares of the electromotive forces generated in a given cell by the lights of the two stars. The photometric method says that they are measured by the thicknesses of certain interposed glass prisms which extinguish the lights, or by polarising apparatus which render the shades of the transmitted lights "equal." Hence we may expect, perhaps, a fair amount of agreement between the two methods, if we are comparing two or more stars of the same colour. Thus, in the photoelectric method, we have for any two stars

$$
n^{\prime}-m=5 \log _{10} \frac{\mathrm{E}}{\mathrm{E}^{\prime}} . . . .
$$

Applying this to Arcturus and Reyulus, and taking the magnitude of the former as 2 , we find the magnitude of Regulus to be I'33. In Miss Clerke's "System of the Stars" (Appendix), Regulus is quoted as $1 \% 4$, Arcturus being 2 .

Comparing in the same way Procyon and Regulus, the latter being taken as of magnitude $1 \cdot 33$, the magnitude of Procyon would be 46 . Miss Clerke quotes Procyon as of magnitude 5 .

But no agreement between the two methods is to be expected when two stars of different colours are compared. The photometric method of equalisation seems to be just as meaningless as the ordinary "grease spot" method of attempting to equalise a blue and a red light : In this case the only intelligible comparison of two lights consists in measuring the energies which they radiate per 
unit time per unit area at a given distance-just, for example, as Newton's Second Axiom defines two masses to be "equal" when the same force produces the same acceleration in both ; an equality which is real if the substratum at the basis of all bodies is the same, but merely conventional if it is not.

If the distance of a star is known, we can determine its intrinsic energy, i.e. the quantity of energy which it radiates into all space per unit time.

Thus, let I be the intrinsic energy of a star whose distance from the earth is $\mathrm{R}$; let $\mathrm{E}$ be the electromotive force of its light as measured by the cell ; let $i, r, e$ be the analogous quantities for a candle or any other chosen source of light; and let $\mathrm{A}$ and $a$ be the areas of the aperture of the telescope and the selenium surface in the cell. Then we have

$$
\frac{\mathrm{I}}{i}=\frac{\mathrm{R}^{2} \cdot \mathrm{E}^{2} \cdot a}{r^{2} \cdot e^{2} \cdot \mathrm{A}}
$$

Let us take, for example, a result which Prof. Boys recently told me that he had obtained. He found, in conjunction with Mr. Watson, of South Kensington, that if the light of a standard candle was observed across a valley and almost in the line of sight of Arcturus, the light of the candle and that of the star seemed to be equal when the candile was at a distance of five-eighths, o1 625 , of a mile.

Now, let $x$ be the distance at which the candle light seems to be as bright as that of the star. Then

$$
\mathrm{I}=\frac{i}{\mathrm{R}^{2}}=\frac{x^{2}}{2}
$$

And if $\mathrm{D}$ and $d$ are the diameters of the telescope aperture and the circular layer of selenium in the cell, we have from (3)

$$
x=r \frac{e \mathrm{D}}{\mathrm{E} d}
$$

Put, now, $r=9$ feet, $c=$ IO, $\mathrm{E}=8 \cdot 2, \mathrm{D}=24 \times 25$ millimetres, $d=\underset{2}{2} \mathrm{~m} . \mathrm{m}$., as in our experiments, and we find

$$
\begin{aligned}
x & =3300 \text { feet, nearly } \\
& =62 \text { miles. }
\end{aligned}
$$

This agrees remarkably well with the observation of Prof. Boys.

GEORGE M. MINCHIN.

\section{FUNERAL OF PROFESSOR HUXLEY.}

$\mathrm{I}$ accordance with his own wish, the late Prof. Huxley was buried at the Marylebone Cemetery, Finchley, last Thursday afternoon. The coffin came up from Eastbourne in the morning, and the numerous mourners assembled at the cemetery to meet it. Wreaths from members of the family, and from friends and fellow workers of the great naturalist whose loss we mourn, covered the coffin. The Royal College of Science, with which Huxley was connected so many years, sent a large wreath, and there were also wreaths from Lady Hooker, Mrs. Tyndall, the members of the staff at the Royal Gardens, Kew, Mr. Herbert Spencer, Sir Henry Thompson, Sir Henry Roscoe, Messrs. Macmillan, and the Editor of NATURE, among others.

The funeral service was performed by the Rev. J. Llewelyn Davies, an old friend of Prof. Huxley's, now rector of Kirby Lonsdale, but formerly vicar of Marylebone, where he was for a long time Huxley's neighbour.

The family was represented by Mrs. Huxley, the two sons, Mr. Leonard Huxley and Mr. Henry Huxley, and three daughters, the Hon. Mrs. Collier, Mrs. Waller, and Mrs. Eckersley (the remaining daughter, Mrs. Roller, is in Switzerland with her. husband, who is ill), Mrs. Heath (a niece), and two sons-in-law, the Hon. John Collier and Mr. F. W. Waller.

NO. I 34 I, VOL. 52 ]
No announcements of the funeral were sent out, and the large number of distinguished men who attended, and the various learned Societies that sent representatives, did so on their own initiative. The Royal Society was officially represented by Lord Kelvin, Sir John Evans, Prof. Michael Foster, and Sir J. Lister, many of the Fellows also being present. The Geological Society was represented by Dr. Henry Woodward, Dr. Blanford, and Prof. Bonney. Dr. Frankland, Mr. Crookes, Dr. Thorpe, and Dr. Gladstone were the representatives of the Chemical Society. The mourners from the Royal College of Science included Prof. Rücker, Prof. Norman Lockyer, C.B., Prof. Tilden, Prof. Judd, C.B., Prof. W. C. Roberts-Austen, C.B., Prof. Howes, Prof. Farmer, Dr. Wynne, Mr. J. W. Rodger, and Mr. Woodward. MajorGeneral Sir J. F. I. Donnelly, K.C.B., Major-General Festing, Captain Abney, C.B., Mr. T. Armstrong, Mr. F. R. Fowke, and Mr. A. S. Cole represented the Science and Art Department; Sir William Flower, K.C.B., Dr. A Gïnther, Mr. George Murray, Mr. C. E. Fagan, Prof. Jeffrey Bell, and Mr. F. A. Bather, the Natural Histor Museum ; Prof. Armstrong, Prof. S. P. Thompson, Prof. Perry, and Prof. Ayrton, the City and Guilds Institute Mr. Stanley Boyd, Mr. H. F. Waterhouse, Mr. J. F. Pink, the Charing Cross Hospital Medical School ; Mr. J. J. H. Teall, Mr. F. W. Rudler, and Mr. E. T. Newton, the Geological Survey. In addition to the Fellows of the Royal Society not included in the above, there were present Prof. E. Ray Lankester, Dr. Dallinger, Sir Joseph Hooker, K.C.B., General Strachey, Dr. Lauder Brunton, Dr. Sclater, Prof. Carey Foster, Prof. G. H. Darwin, Sir James Paget, Dr. Burney Yeo, Prof H. Marshall Ward, Prof. Seeley, and Mr. F. Darwin. Among the other mourners were Mr. Walter Troughton. representing Mr. Herbert Spencer, who was prevented by illness from being present, Dr. T. K. Rose, Mr. W. Darwin, Mr. A. H. Heath, Mr. S. Highley, Mr. W. S. Stewart, Major-General Sir Richard Pollock and Mr. D. Pollock, Mr. Alma Tadema, Mr. W. E. H. Lecky, Mr. and Mrs. Humphry Ward, Mrs. Tyndall, Mrs. W. K. Clifford, Mr. Henry James, Mr. Mark Judge, Mr. H. Saunders, Dr. Semon, Mr. F. Macmillan, Mr. G. L. Craik, Mr. Clodd, Mr. G. Griffith, Lady Staveley Hill, Mr. Paynter Allen, Mr. John Boyes, Mr. Spencer Walpole, Mr. Woodd Smith, Dr. J. Johnson, Mr. James Hulme, Mr. Stanley Edwards, Dr. Glover, Mr. T. B. Windsor, the Rev. D. D. Jeremy, Dr. J. Malecki, Mr. J. Spiller and Mr. and Mrs. Briton Rivière.

The funeral was at first announced to take place at 3 o'clock, whereas the time fixed upon was $2 \cdot 30$. Owing to a delay in the train, a number of workers in science, from the Midlands and the North of England, did not arrive at the cemetery until the ceremony was over, and thus, to their deep regret, they were deprived of the melancholysatisfaction of being present when the remains of an esteemed master and friend were laid to rest.

The memory of Huxley will always be cherished among. men of science, and it is imperative that there should be a permanent memorial of some kind to show the world how great is their regard for him. The memorial should be a truly national one, and not limited to any particular institution. We understand that the Dean of Westminster is willing that a tablet shall be erected in the Abbey if desired, and this is one of the forms which the memorial might take. Sir William Flower suggests another form, in a letter to the Times of Monday. He writes:

"In the great hall of our national Museum of Natural History the noble statue of Darwin will hand down to posterity the image of the man as he appeared to all who knew him in life. Near this will soon be placed another statue remarkable for the accuracy with which the striking personality of Owen is represented, as all who see it now at the Royal Academy Exhibition can testify. 